\title{
The natural environment as a significant factor in farmers and fishermen's notions of peace
}

\author{
Guiraldo C. Fernandez, Jr. ${ }^{1 *}$ Sister Geraldine D. Villaluz, RSCJ ${ }^{2}$
}

\begin{abstract}
This study delves into the aspect on how the farmers of Barangay Kambonggan, a mountainous coconut farming community thirteen kilometers from the poblacion of Baybay, Leyte, Philippines and the fishermen of the coastal fishing community of Sitio Lapawon, Barangay Santo Rosario of the same locality understand the notion of Peace through the qualitative research method of Phenomenology. This study finds out that the farmers understand peace in relation to their concept of kinabuhi ug kinaiyahan (life in relation to the environment). The farmers believe that peace is only achievable if Mother Nature favors them in their livelihood through good weather conditions that suit coconut farming and crop cultivation. Yet, the farmers are certain that Nature's cooperation is acquired only when they do their share in the care and conservation of the environment. Hence, for farmers, the attainment of peace entails a two-way process. This study also finds out that the fishermen's notion of peace is also greatly influenced by Mother Nature. In fact, fishermen understand peace in relation to the concept of Dagat maoy kinabuhi (the sea is life). Since the sea is part of fishermen's lives, this study finds out that the behavior and generosity of the sea also determines the fishermen's understanding and experience of peace. Like the experience of their farmer counterparts, achieving peace also requires a two-way reciprocal process. This paper concludes that the farmers and fishermen's notions of peace are greatly influenced by the behavior of the environment towards their way of life.
\end{abstract}

Keywords: Kinabuhi (life), Peace, Natural Environment, and Conservation.

\section{INTRODUCTION}

It is a consensus among people that there is peace when there is no experience of chaos or any form of disturbance in the lives of each and every person. There is peace when people from all walks of life can freely do what they want and can really

${ }^{1}$ Department of Liberal Arts and Behavioral Sciences, Visayas State University, Baybay City, Leyte,Philippines

${ }^{2}$ School of Education, Graduate Teacher Education, University of San Carlos, Cebu City, Philppines

\footnotetext{
* Corresponding Author. Address: Department of Liberal Arts and Behavioral Sciences, Visayas State University, Baybay City, Leyte; e-mail: guiraldo.fernandez@vsu.edu.ph DOI: 10.32945/atr40110.2018
} 
The natural environment as a significant factor in notions of peace

academic sense, peace is defined as a state of quiet or tranquility, freedom from disturbance and agitation, calm, and repose. It can also mean the absence or cessation of war, general order and tranquility, freedom from riot or violence, a state of reconciliation after a strife or enmity, freedom from mental agitation and anxiety, and spiritual content (Read 2004). In Baybayanon-Sinugbuanon, peace is translated as kalinaw, kahilom, or malinaw which also means a state of rest and tranquility, spiritual content, and calm (Cabonce 1983). The word kalinaw is a noun since it is the Baybayanon-Sinugbuanon name or term for peace. Yet the word malinaw also connotes peace but it is often used as an adjective since it describes a place or an event to have an ambience or a sense of peace. Peace's definition varies from how people perceive it to be. The way people think about peace has been there since the dawn of civilization. However, the requirements of peace change with the changing world (Ajos 1997).

Hence, the notion of peace goes beyond its traditional definition of just a cessation or absence of conflict and hostility. After all, peace originates from the Latin word pax, meaning fasten, so as to achieve a stable condition and also used by translators to refer to the Hebrew word shalom which also means safety, welfare, and prosperity (Harper 2001). This observation seems to be true since just very recently, a new challenge to peace has emerged. There have been relentless assaults of the earthly habitat that are heightening the global risk of deadly conflict. Climate change, for instance, has tended to increase the chances of natural disasters and extreme natural events that led to social disruptions and aggressive competition for scarce materials (Tipson 2013).

With this, it could be surmised that peace could be also construed to mean stability in a community's place of habitation which also refers to the absence of calamities that surely affect the lives of the marginalized people in the society, many of them farmers and fishermen. In famers and fishermen's lives, the absence of calamities would mean prosperity while the occurrence of it would lead to the scarcity of their basic needs that disrupts their experience of peace. After all, the lives and livelihood of farmers and fishermen are closely bonded and intertwined with natural environment.

At present, the ambience of peace in the City of Baybay of the Province of Leyte has not been seriously challenged. Unlike the Muslim Mindanao areas where peace is often disturbed by cultural conflicts that often result to wars and injustices, the most recent challenge to peace in Baybay City, Leyte was the devastation caused by Typhoon Yolanda (Haiyan) in November 2013 that caused damage to millions worth of properties and had greatly affected the lives of Baybayanons, especially farmers and fishermen. Hence, it can be construed that Baybayanons' issues of peace are very much different from those of the other Filipinos who live in other provinces.

This study provides venues for people, Baybayanons, to understand peace in relation to the challenges and problems that affect their lives. One way of achieving this is to look into how the farmers of Barangay Kambonggan Baybay, Leyte and the residents of the fishing community of Sitio Lapawon, Barangay Santo Rosario of the same locality understand peace. The farmers and fishermen's peace notions would provide another dimension on how peace is construed as they are derived from people living very close to nature considering that the farmers' homes are built within the vicinity of their farms which are located in the mountainous areas of Baybay, Leyte while their fishermen counterparts built their homes very close to 
the sea. This is important since, as mentioned earlier, one of the biggest challenges to peace Baybayanons have recently confronted was brought about by the wrath and fury of nature. It is in this context that this study determines how peace is perceived in relation to the experiences of farmers and fishermen.

\section{METHODOLOGY}

\section{Research Design}

This study is qualitative by nature and specifically involves the method of phenomenology. It is qualitative in the sense that it is designed to arrive at notions of peace of farmers and fishermen by delving into the meaning of behavior, language, and aspects of how they live, relate, and interact with each other in their community (Creswell 2007). This study utilizes the phenomenological method in the aspect that it delves into the experiences of the research partners as expressed in their lived and told stories as starting points (Creswell 2007). With regards to this study, this form of phenomenology follows Martin Heidegger's contention that it is impossible to bracket researchers' assumptions and reflections from their research. Instead, in the hermeneutic approach, it is possible to bridle researcher assumptions through scrutinizing by continually questioning and critically reflecting upon one's pre understanding and involvement in the Phenomenon (Dahlherg 2006). In one way or another, the focus is toward illuminating details and seemingly trivial aspects within experience that may be taken for granted in people's lives with a goal of creating meaning and achieving a sense of understanding (Wilson \& Hutchinson 1991).

Not only that, hermeneutic phenomenology also aims at producing rich textual descriptions of the experiencing of selected phenomena in the life world of individuals that are able to connect with the experiences of people collectively. From identification of the experience of phenomena, a deeper understanding of the meaning of that experience is sought (Smith \& Vandenburg 1997). Hence, in order to have a full understanding of what this study's respondents want to convey, the use of any language that the respondents are most comfortable with is utilized. After all, to understand the life world, people need to explore the stories that others tell of their experiences (Langdridge 2005). These experiences are best expressed through the use of the respondents' most comfortable language and it is the researchers' task to come up with meaningful insights so that what the respondents are saying or expressing would be interpreted and deciphered properly to give justice to the realities that the respondents are trying to express or convey to the researchers.

\section{Research Procedure}

In the process of deciphering the natural environment's influence on the farmers and fishermen's notions of peace, the researcher went into several sessions of Key Informant Interviews (KII) and focus group discussions to farmers and fishermen in two communities in Baybay, Leyte, Philippines. In this study, purposive sampling was utilized to narrow down and identify respondents from two farming and fishing communities. In the conduct of the research, the researcher visited the respondents and set up interviews and focus group 
The natural environment as a significant factor in notions of peace

discussions in a place, time, and manner that the respondents found most comfortable. The interviews and focus group discussions were unstructured, casual, and conversational. Conversational interviewing and discussions had generated a first person description of the experience (Van Manen 1990) since they had elicited a variety of types of rich data that manifested how participants had interpreted and used language as well as how participants had explained their decisions or actions or narrative data (Cohen et al 2000).

During the course of the interviews and focus group discussions, the following questions were asked: What is your understanding of peace? What are the words that connote or relate to peace? and how do you achieve or arrive at a sense of peace? The researcher gained permission to digitally record the interviews. Digital recording allowed the researcher to focus on the interview, attend to the participants, record memos and accurately capture participants' tone, inflections, and pauses. After the data were gathered from several sessions of key informant interviews, thematic analysis was done with the use of the hermeneutic circle of reading, interpretation, and reflective writing in order to identify phenomenological themes that were essential to represent the structure of experience.

The process began with the immersion in the data through reading and rereading in order to engage with the meaning of the texts for interpretation that facilitated coding (Van Manen, 1990). After the process of data interpretation, the researcher assessed the trustworthiness of the data analysis by presenting the study's interpretation to the respondents. Hence, the final draft of this study had been presented to the respondents for their appraisal. Lastly, consent to publish the respondents' answers to the interview questions have already been given by the respondents themselves.

\section{RESULTS AND DISCUSSION}

\section{The Environment and the Farmers' Notion of Peace}

The farmers of Barangay Kambonggan, Baybay, Leyte understand peace in close relation with the environment. For farmers, care for the environment is an important element in the realization of any person's quest to attain peace. Hence, farmers understand the notion of peace in relation to the concept of kinabuhi sa kinaiyahan (life in relation to the environment). They look at peace in relation to their work as tillers of the land. Hence, the concept of kinabuhi sa kinaiyahan is felt to be real when farmers feel that there is an ambience of pagbulig sa panahon (favorable weather conditions) as they strive to earn a living and survive. Famers refer to this as igo-igo nga nga panahon which entails the presence of the right and exact amounts of sunshine and rainfall or a well-balanced climate that suits crop cultivation and production, and hence, give farmers the opportunity to earn more. This enables them to secure their basic necessities as well as afford some of the little luxuries that life offers.

With this at hand, there is a sense of peace in the lives of farmers since they no longer have to worry about food for the family in every meal because of the abundance of harvest that comes as a result of favorable weather conditions, a taste of luxury because of the surplus of their harvest that gives them additional spending opportunities, and an ambience of worry-free homes. 
After all, igoigo, is the vernacular for exact, substantial, fair, or moderate (Ortega 2014) while panahon could also mean weather conditions. With igoigo nga panahon, there is a big chance for the emergence of what farmers refer to as mamusaw ang bunga sa lubi ug mga pananom. This is also construed to mean peace since the Baybayanon-Sinugbuanon word mamusaw is understood by farmers as the time when coconut trees and other plants would start to produce fruits which would later become ripe for the harvest. This gives farmers a sense of hope for better days to come. With abundant fruits in coconut trees and crops, there is already a promise of a good harvest. A good harvest would give farmers a sense of peace since it would enable them to support their families and also enjoy the comforts in life once in a while. With mamusaw ang bunga sa lubi ug mga pananom present, the farmers would feel that Mother Nature has blessed them and their work which leads them to the attainment of inner peace.

However, there is one thing that could destroy the farmers' sense of peace brought by mamusaw ang mga bunga sa lubi ug mga pananom. This is referred to as the occurrence of bagyo or storms that destroy farmers' crops and properties. Hence, the absence of storms or walay bagyo would cement the farmers' possession of peace (Fernandez 2017). The word walay in BaybayanonSinugbuanon means no, with no, and having no (Ortega 2014) while the word bagyo means a disturbance of the atmosphere accompanied by rains, lightning, and winds (Streblow 2007).

Hence, walay bagyo means the absence of typhoons or cyclones. According to the farmers, there is peace when there are no typhoons since typhoons could damage the coconut trees which many, if not all, of them depend on as a means of making a living. Not only that, typhoons also destroy their other crops like sweet potatoes, cassava, yam, their vegetable gardens which serve as an alternative source of income, and the banana plants which also serve as an alternative source of food for many of the farmers. When there are typhoons, life would be hard for the farmers since it connotes the destruction of crops which eradicate the potential for farmers to earn their share of the income, not to mention the damage to properties that any given typhoon would bring.

Moreover, walay bagyo (the absence of storms) also connotes the essence of peace since it brings an atmosphere of prosperity. Hence, peace, in one way or another has something to do with what nature brings to farmers. Typhoons are part of nature's way of unleashing its fury. In the town of Baybay, in the province of Leyte, typhoons are not those that are least expected considering that Leyte is one of the country's frequent typhoon paths. In November 2013, Typhoon Yolanda ravaged Leyte that it affected the lives of the farmers of Barangay Kambong-gan since many of the coconut trees in the area were destroyed during the catastrophe. Their other crops were also damaged which made life more difficult, most especially, the months after.

With farmers benefitting much from nature's kindness, it cannot be denied that their work is dependent on the earth's capacity to make their plants and crops grow and bear much fruit. The farmers understand that for the environment to favor their work and endeavors, they have to take good care and preserve the environment so that it would reciprocate the good things that they give to Mother Nature. This is what the farmers understand as pagbulig sa tawo sa kinaiyhan (human beings' care and support for the environment). This expresses the need for farmers to take 
care of Mother Nature so that they could also reap the good things that nature gives to humankind in the very near future.

In expressing the words pagbulig sa tawo sa kinaiyhan into action, farmers of Barangay Kambonggan have asserted that one way of doing their share of caring for the environment is to be extra careful that in their drive to make gardens and farms in the mountains, they have to see to it that they won't advertently or inadvertently cut tress in the process. This preserves the existing trees and enables the young trees to grow and serve as instruments to prevent landslides which are already rampant in their area. For the farmers, they would rather preserve and let the trees grow than suffer the pains that environmental disasters will bring. After all, Mother Nature provides human kind with things that they need to survive. Yet, nature is also totally fierce and destructive when neglected, abused, and unreasonably exploited.

Moreover, the farmers of Barangay Kabonggan also believe that they can also preserve the richness of the soil in their farms by using organic fertilizers instead of their synthetic counterparts. For the farmers, aside from the fact that organic fertilizers like carabao manure, cow manure, and chicken dung are inexpensive, they are also sometimes free and are friendly to the soil. Such fertilizers do not contain chemicals that are, more often than not, destructive to the fertility of the soil in the long run. Hence, with the trees preserved and the farmers' farms retaining its richness, farmers could feel safe in their community, and at the same time, have greater chances to reap the right amount of their harvest enough to sustain them for the greater part of the year. For the farmers, this is peace since they are at peace with Mother Nature and are also capable of providing for their families' needs.

Looking at the aspects where farmers understand the notion of peace, it can be construed that the environment plays an important factor in the formation of the said notion. The fate of the lives of the farmers of Barangay Kambonggan, Baybay, Leyte are closely entwined with their farms whose capacities to produce is dependent on the quality of the behavior of the natural environment towards them. When weather conditions suit coconut farming and crop cultivation for the greater part of the year, the farmers would also experience a sense of peace for a longer period of time since favorable weather enables farmers' coconut trees to yield much fruit and crops to give abundant harvests which give farmers greater capacities to support their families' needs, greater spending powers, and incur bigger incomes enough to live decent, comfortable, and peaceful lives.

However, in instances where Mother Nature does not favor what farmers need to grow their plants and crops as well as the care for their coconut trees like the occurrence of too much rains and prolonged droughts, farmers' lives are made more difficult. The majority of the farmers of Barangay Kambonggan are not very well educated. Hence, finding jobs are quite difficult to accomplish. Most of the farmers during these times engage themselves in farm related hired manual labor which farmers refer to as salibut. Therefore, when there is the absence of pagbulig sa panahon (favorable weather conditions), many of the farmers' lives would be hard and difficult. To persuade Mother Nature to favor their endeavors as tillers of the land, the farmers have to also do their share to care and support for the wellbeing of the natural environment. This is where pagbulig sa tawo sa kinaiyahan (human beings' support and care for the environment) has to be 
that there will pagbulig sa panahon (favorable weather conditions). The farmers are very much aware that it is always a two-way and reciprocal process. There will pagbulig sa panahon if there is the presence of pagbulig sa tawo sa kinaiyahan. With these two elements present, farmers could live peaceful and happy lives (Fernandez 2017).

\section{The Environment and the Fishermen's Notion of Peace}

The fishermen in Sitio Lapawon, Barangay Santo Rosario, Baybay, Leyte conveyed in Baybayanon-Sinugbuanon their own concepts of peace. For the fishermen, peace is defined in relation to the concept of Dagat Maoy Kinabuhi (the sea is life). Dagat Maoy Kinabuhi refers to the fishermen's relationship with the sea as the extension of their lives. Their lives are primarily dependent on the conditions of the sea which is the source of their livelihood. From the sea they source out their food and thus their income. This is where they get funds for their children's tuition and other basic needs. The Fishermen conceptualize the notion Dagat Maoy Kinabuhi into the aspect wherein the environment plays a very important role in their lives.

For fishermen, when the environment blesses their endeavors in life, they could live happily and peacefully. This is what they referred to in BaybayanonSinugbuanon as pagbulig sa kinaiyahan. Pagbulig means to cooperate (Ortega 2014) while kinaiyahan simply means nature or the environment (Ortega 2014). Hence, Pagbulig sa Kinaiyan in the Baybayanon-Sinugbuanon language means favorable weather conditions that nature gives to the fishermen in relation to their livelihood since Mother Nature has cooperated with them in their thrust to earn a living and their pursuit to live contented and quiet lives. The fishermen specifically expressed the notion of pagbulig sa kinaiyahan through the use of the words walay bagyo (the absence of storms), walay habagat (the absence of southwest monsoon winds), linaw ang dagat (calm sea), linaw ang pang huna-huna (peaceful thoughts), linaw ang panginabuhi (peaceful means of making a living), and daghan ang kuha nga isda (abundant catch).

For the fishermen, pagbulig sa kinaiyahan is identical with peace since it connotes the right sea conditions conducive to fishing. Here the sea is calm, the rains do not come, the winds are not strong, and the temperature is not very cold. These conditions signify an abundant catch and that weather conditions are not a challenge to the fishermen, as the cold is tolerable for the human body and that safety is not compromised. Aside from that, the fishing community would be in a state of relative peace because the fishermen and their families would not be disturbed by bad weather conditions that cause damage to their boats, the payaws or the fishshades, as well as their houses that are built near the sea. As long as there is that ambience of pagbulig sa kinaiyahan, everything is well with them (Fernandez 2017).

Walay habagat is also understood as a state of peace by the fishermen. It is the absence of strong southwest monsoon winds which bring high destructive waves to the shores of many coastal fishing communities in the western part of Leyte where Baybay is situated. If there is the presence of walay habagat in the fishing community of Sitio Lapawon, the fisherfolks and their families could live in peace, even if temporary. For the fisherfolks, walay habagat is equal to calm seas that suit fishing, a quiet and enjoyable neighborhood, and a place where damage to 
The natural environment as a significant factor in notions of peace

properties due to natural calamities is a distant reality. Given these things, walay habagat would definitely bring degrees of peace to fishermen and their families. Walay habagat also relates to the words linaw ang dagat, linaw ang pang hunahuna, and linaw ang panginabuhi (Fernandez 2017).

The words linaw ang dagat (calm sea) also connotes the possession of a sense of peace among fishermen since it means that the seas are quite and tranquil that fishermen will be put in a situation where to neglect to listen to the sound of silence would not be an option. After all, the sea and the lives of the fishermen are intertwined in such a way that a peaceful sea is evidently equivalent to a peaceful life. To view peace as the absence of unwanted disturbances in one's life, the words linaw ang dagat connote a peaceful atmosphere where the sea is quiet and one can hear the voice from within since the sea's calmness would also calm one's inner self. Thus, the sea's calmness presupposes the absence of strong winds and tall waves, reflective of the character of inner peace. For the fishermen, ang kalinaw sa dagat would also bring kalinaw or peace on one's thoughts. With this, the fishermen could simply enjoy the peace in their lives --free from worries and problems that life cannot do without. Furthermore, the words linaw ang dagat also flows on to the concept of linaw ang pang huna-huna. This is the aspect where a person enjoys the possession of peaceful thoughts, free from the worries of making both ends meet at the end of the day because if the sea is calm, the fishermen are more or less assured of an income enough for their families' needs. This, at least, satisfies the fishermen's most basic requirement in life which is a prerequisite in attaining peace (Fernandez 2017).

Linaw ang pang huna-huna is also linked with the phrase linaw ang panginabuhi (peaceful means of making a living). Linaw ang paginabuhi relate very much to linaw ang dagat (calm sea) since the fisherfloks are naturally dependent on the bounty of the sea. If linaw ang dagat is a reality, it follows that there is a great possibility for an abundant catch for every fisherman who will venture into the calm seas since the payaws (fish shades) that serve as the converging points and resting places of fishes remain undisturbed. Aside from that, the fishermen are safer in calm seas and their safety would be one of the last things that they have to worry about. With the presence of a calm sea, the fishermen could freely fish in the open sea. A greater chance is therefore afforded them to earn their keep, as the sea is friendlier when southwest monsoon wind is inactive. Lastly, daghan ang kuha nga isda (abundant catch) also means peace for fishermen because it presages a bountiful catch and therefore, a bigger income. With bigger incomes, the fishermen would no longer have the problem of providing for their families' most basic needs. They can arrive at a sense of peace since the task of providing for their families would no longer be a problem to be addressed if there is daghan ang koha nga isda (Fernandez 2017).

Another manifestation of the environments' act of favoring the fishermen's endeavors in life refers to the absence of storms for a longer period of time. This is referred to by the fishermen as walay bagyo. Walay bagyo would bring peace to fishermen's lives since with the absence of storms, fishermen's things and possessions, most especially, those things that they use in fishing would be preserved and would not be destroyed. Storms are a natural challenge for the 
fishermen environmentally and economically. It is a challenge environmentally because with the presence of storms, they cannot go out to the sea and fish. It is a challenge economically because they destroy properties and fishing implements. With this, it is easy to see why walay bagyo would mean peace for fishermen.

Moreover, the fishermen also understand the concept of dagat maoy kinabuhi (the sea is life) in relation to the context of pagbulig sa tawo sa kinaiyahan (human beings' support and care for the environment). This refers to fishermen's actions to confront challenges to the environment's wellbeing which are mostly manmade. Pagbulig sa tawo sa kinaiyahan refers to fishermen's efforts to protect the seas in order to maintain and sustain its capacity to support the fishermen and their families. Again, pagbulig means to cooperate (Ortega 2014) while kinaiyahan simply means nature or the environment (Ortega 2014). To define it further, Kinaiyahan also means everything in the world that is not made by people, such as plants, animals, and weather (Streblow 2007). Hence, pagbulig sa tawo sa kinaiyahan manifests actions that people do for nature conservation. This enables them to fulfill their obligation as stewards of the environment. By conserving nature, people would reap the good things that nature gives to humankind since it is nature's reason for being. However, it is also important to know that while nature and the seas give fishermen blessings when properly cared and preserved, it would also be very cruel and fierce when abused.

Synonymous to peace with respect to man-made environmental challenges are walay manglagtang (the absence of the use of and indigenous poison in fishing), walay mugamit ug tiro sa panagat (the absence of the use of dynamite fishing), walay mugamit ug hulahop sa pangisda (the absence of a fishing method that use nets that reach the seabed with small holes in them), walay dagko nga sensuro nga musod sa pangisdaan (the absence of large scale fishing vessels within the vicinity of the fishermen's fishing grounds), and walay daghang basura nga di malata sa dagat (the absence of non-biodegradable trash in the sea). These phrases are at once relatable to pagbulig sa tawo sa kinaiyahan (human beings' support and care for the environment).

Walay manglagtang relates to peace since it means the preservation of small young fishes. Lagtang is a poison derived from the seeds of anamirta cocculus (Umali 2013). It is a potent poison for fish commonly used by local unscrupulous fishermen. Lagtang kills fishes, big and small alike, which makes fishing easy for unscrupulous fishermen. Nonetheless, this results into the eradication of fishes since they could no longer regenerate because even small fishes are caught. In sum, there would be a decrease of catch for the fisherfolks which also means a decrease in income. With walay manglagtang, fishes could regenerate over and over since the fishermen will only catch those fish that are already mature for the catch. With this, a bountiful catch can be sustained for a long period of time, promising days of peace and prosperity for the fishermen (Fernandez 2017).

Walay mogamit ug tiro sa panagat (the absence of the use of dynamite fishing) is construed by fishermen as similar to the word peace since if walay mogamit ug tiro sa panagat, the fishing grounds could maintain its abundance of fish. Tiro sa panagat means dynamite fishing and the use of dynamite as a fishing method 
The natural environment as a significant factor in notions of peace

cause great damage to the fishes. Not only that, the corals that support the lives of many marine resources would also be destroyed. Hence, it would slowly eradicate the abundance of fish in the area where the fisherfolks used to fish. Furthermore, dynamite fishing would also put the lives of many fisherfolks at risk. Walay mugamit ug tiro sa panagat would naturally mean peace to the research partners since it preserves the abundance that exists in the fishing grounds. The prevalence of fishes to catch in the area remains and the catch for the fishermen is assured. For the fishermen, this means peace because a bountiful sea will bring peace to their lives, sustaining them and their families (Fernandez 2017).

In conjunction with walay mogamit ug tiro sa panagat, walay mogamit ug hulahop sa pangisda also means peace to the fisherfolks. Hulahop sa pangisda is a fishing method in which fishing boats use nets that reach the seabed with very small holes in them. This assures a big catch for the fisherfolks. However, the result would be devastating for fishing's sustainability since the long nets would eventually destroy the corals and the nets' small holes would enable the fisherfolks to catch big and small fishes. This again would pose a problem for the fishes to regenerate since such method of fishing includes in its catch small fishes that would someday reproduce. With the small fishes included in its catch, the fishing grounds' sustainability would be compromised and other fishermen's future catch would be greatly diminished. Hence, walay mugamit ug hulahop sa panagat would mean peace to the fishermen because of the preservation of their fishing grounds which is their major source of income. After all, a rich fishing ground could mean a bigger catch which would also translate to bigger income (Fernandez 2017).

Moreover, here is this man-made threat that still challenges the sense of peace for the fishermen. This challenge is the entry of large scale fishing vessels into the fishing grounds of small-time fishermen. These fishing vessels are referred to as dagko nga sensuro. These vessels are equipped with state of the art fishing equipment such as sonar, fish finder, mechanized nets, and high-speed engines. They are designed to catch tons of fish in a single fishing night. However, there is a restriction that such vessels should not fish inside the seven-kilometer area from the shoreline. In short, the fishing grounds within the seven-kilometer distance from the shores are exclusive only to the small-time fishermen. But this is not always the case for the fisherfolks of Sitio Lapawon. Large-scale fishing vessels or dagko nga sensuro often pass by the seas of Sitio Lapawon and in the process deplete the marine resources in the area. This results to the fishermen's fewer catch. This also decreases the fishermen's capacity to buy the things they need which, more often than not, serve as causes for the disturbance of peace in their lives. Hence, the words walay dagko nga sensuro nga mosud sa pangisdaan (the absence of large scale fishing vessels within the vicinity of the fishermen's fishing grounds) would mean peace to the fishermen since it means that their fishing grounds would not be over-fished by large-scale fishing vessels. This results in the preservation of the marine resources in the area. Their fishing ground could sustain them since fishes go by the natural process of regeneration. This provides fishermen fishes for the greater part of the year (Fernandez 2017). 
The last phrase research partners construe as synonymous to peace in this category is walay daghang basura nga di malata sa dagat (the absence of nonbiodegradable trash in the sea). This man-made challenge to the environment is very simple yet it poses a great problem to the fisherfolks of Sitio Lapawon. For the fishermen, the presence of garbage in the seas drives away the fishes from their fishing grounds. Since Sitio Lapawon is a community that is a little bit isolated by a small gap divided by the sea from the main part of Barangay Santo Rosario, it is impossible for the garbage trucks of the local government of Baybay to reach Sitio Lapawon. The bridge that connects the Sitio to the Barangay is too small for fourwheeled vehicles to cross. Hence, to dispose of their garbage, the Sitio's residence only have the options to bury their garbage, burn their garbage, or throw their garbage into the sea. Of the three options, only the first seems friendlier to the environment. The other two are environmental hazards. The option of throwing the garbage to the sea seems improper. Not only that it is improper, it drives away the fishes in the nearby sea and hence, made fishing a little bit difficult. According one fisherman respondent, the presence of basura or trash in the sea could diminish their catch since fishes tend to get away from trashes since they disturb the fishes' natural habitat. Hence the words way daghang basura nga di malata sa dagat (the absence of trash in the seas) are synonymous with peace for the research partners since it refers to an undisturbed fishing ground that could sustain them for the days to come.

Taking into consideration that fishermen's notion of peace are formed from their experiences where the sea cooperates when they venture out to the sea to fish as well as their experiences of quiet and tranquil nights because of the stillness of the sea, it is not difficult to construe that the behavior of the sea greatly influences the fishermen's understanding of peace. Since the sea is part of the natural environment, the natural environment is part and parcel of the fishermen's formation of their notion of peace. Like their farmer counterparts, the fishermen also understand that arriving at a sense of peace also entails a two-way and reciprocal process. There can only be pagbulig sa panahon (favorable weather conditions) if there is the presence of pagbulig sa tawo sa kinaiyahan (human beings' support and care for the environment). The fishermen of Sitio Lapawon have come to a realization that like the majority of the Filipinos, they have to be in harmony rather than mastery over nature (Swee-Hin 1987). After all, the sea gives fishermen an abundance of catch if fishermen also do their share of protecting and caring for the seas. As mentioned earlier, the fishermen's understanding of peace is anchored on the concept of dagat maoy kinabuhi (the sea is life). Hence, it is a moral imperative for fishermen to safeguard the sea's well-being so that they could in turn enjoy peaceful and worry-free lives.

\section{CONCLUSION}

This study has concluded that the farmers and fishermen of Barangay Kambonggan and Sitio Lapawon notions of peace are greatly influenced by the behavior of the natural environment towards their way of life. On the part of the farmers, there is peace when weather conditions suit coconut farming and crop cultivation. This is what farmers refer to as pagbulig sa panahon. Pabulig sa 
The natural environment as a significant factor in notions of peace

panahon. Pabulig sa panahon is equivalent to peace since it enables farmers to have a better harvest that can also be construed to mean greater chances to have greater income. Hence, the natural environment also has a big role on the economic aspect of the farmers' lives which is one of the determinants for the farmers' attainment of peace. Like their farmer counter parts, the fishermen also construe peace in relation to the presence of favorable weather conditions that suit fishing. This is what fishermen also refer to as pagbulig sa panahon (favorable weather conditions that suit fishing). Pagbulig sa panahon for fishermen refers to the presence of calm seas that would also give fishermen the opportunity to have an abundant catch. An abundant catch would mean better income that enables fishermen to secure their families' basic needs. This also manifests the environment's role in the economic aspect of fishermen's lives which also is a determining factor on how fishermen understand peace.

Aside from the economic aspect, pagbulig sa panahon (also construed by both farmers and fishermen to mean good and fair weather that suit crop cultivation and fishing) also mean peace to the farmers and fishermen in the sense that good weather enables farmers to enjoy the fresh air in the mountains and the fishermen to enjoy the soft breeze that accompany the calm sea that are both reflective of the characteristic of inner peace. Lastly, farmers and fishermen are aware that to be in harmony and at peace with nature, they should do their share in protecting the environment so that nature's built-in balance will be preserved for the longest time possible. It is always a two-way process. The farmers and fishermen are aware that in order to arrive at an ambience of pagbulig sa panahon (both are construed by farmers and fishermen to mean favorable weather conditions that suit coconut farming and crop cultivation or favorable weather conditions suitable for fishing), it is a necessity for them to do things that are geared towards support and care for the environment. This is what they refer to in the vernacular as pagbulig sa tawo sa kinaiyahan. Therefore, pagbulig sa panahon necessarily requires pagbulig sa tawo sa kinaiyahan. This is how farmers and fishermen understand peace - a two way recipropcal process. With these present, farmers and fishermen could live harmonious and peaceful lives.

\section{ACKNOWLEDGMENT}

The author would like to thank Visayas State University for the fellowship scholarship grant that it has given to the author, without which, this study would have not been completed. The author would also like to thank Barangay Captain Eduard Marque Guinocor of Barangay Kambonggan, Baybay, Leyte and Barangay Captain Benito Abapo of Barangay Santo Rosario, also of Baybay, Leyte for allowing the author to conduct the study in their respective barangays. Last but not least, the author would also like to thank the famers of Barangay kambonggan and the fishermen of Sitio Lapawon, Barangay Santo Rosario for making themselves available during the focus group discussion sessions and personal interviews. 
Fernandez \& Villaluz

\section{REFERENCES}

Ajos R. 1997. Teaching the Meaning of Peace in Schools. The Modern Teacher, 46:95.

Cabonce R. 1983. An English-Cebuano Visayan Dictionary. Isabela Cultural Corporation, Mandaluyong City.

Cohen M, Kahn D \& Steeves R. 2000. Hermeneutic phenomenological research: A practical guide for nurse researchers. Sage Publications, California.

Creswell JW. 2007. Qualitative inquiry and research design: Choosing among five approaches ( $\left.2^{\text {nd }} e d n\right)$. Sage Publications, California.

Dahlberg K. 2006. The essence of essences: The search for meaning structures in phenomenological analysis of lifeworld phenomena. International $J$ Qualitative Studies on Health \& Well Being, 1(1):11-19.

Fernandez GC. 2017. Integration of Ethnolinguistic Peace Perspectives for Peace Education in the Introductory Philosophy Course for K to 12 Senior High School (PhD dissertation), University of San Carlos, Cebu City.

Harper D (ed). 2001. Peace. Accessed January 7, 2018 from https://www. etymonline.com/columns/post/abbr?ref=etymonline_footer

Langdridge D. 2005. Phenomenological psychology: Theory, research and methods. Pearson, London.

Ortega PA (ed). 2014. Visayan-Cebuano-English Dictionary. Ropredave Book Supply, Mandaluyong City.

Read A. 2004. The New International Webster's Comprehensive Dictionary of the English Language. Typhoon International Corporation, Naples and Florida.

Smith SJ. 1997. Phenomenology of Educating Physically. In: D. Vandenburg (Ed.), Phenomenology and Educational Discourse. 119-144, Durban: Heinemann.

Streblow L and Flores R. 2007. The New Webster's Standard Dictionary (with Philippines' major eight and special supplements: encyclopedic, international, illustrated and revised edition), Vol 1 \& 2. Kimball Enterprises, Manila.

Swee-Hin T and Cawagas V. 1987. Peace Education: A framework for the Philippines. Phoenix Publishing House, Quezon City.

Tipson F. 2013 February. United States Institute of Peace Special Report: Natural Disasters as Threats to Peace. Accessed January 7, 2018, from www.usip.org

Umali G. 2013. Lagtang. Accessed September 25, 2015 from Philippine Medicinal Plants at http://www.struartxchange.com/Lagtang.html.

Van Manen M. 1990. Researching lived experience: Human science for an action sensitive pedagogy $\left(2^{\text {nd }}\right.$ edn). Althouse, London.

Wilson $\mathrm{H}$ and Hutchinson S. 1991. Triangulation of qualitative methods: Heideggerian hermeneutics and grounded theory. Qualitative Health Research, 1:263-276. 